NEZHYVA Mariia,

$\mathrm{PhD}$ (Economics), Associate Professor of the Department of Financial Analysis and Audit Kyiv National University of Trade and Economics Kioto str., 19, Kyiv, 02156, Ukraine

E-mail: m.nezhyva@knute.edu.ua ORCID: https://orcid.org/0000-0002-3008-5338
MINIAILO Viktoriia, $\mathrm{PhD}$ (Economics), Associate Professor of the Department of Financial Analysis and Audit Kyiv National University of Trade and Economics Kioto str., 19, Kyiv, 02156, Ukraine

E-mail:v.miniailo@knute.edu.ua ORCID: https://orcid.org/0000-0001-5867-7135

\title{
DIGITALIZATION OF AUDIT IN THE CONDITIONS OF THE COVID-19
}

The main tendencies of audit digitalization in the conditions of economic transformation are considered. It is established that audit should be conducted in full compliance with international auditing standards, despite the problems associated with COVID-19. It is substantiated that technological integration of audit on the basis of modern information systems increases efficiency of analytical work of the auditor.

Keywords: eco-anxiety, coronavirus, COVID-19, digitalization, audit.

Неживая М., Миняйло В. Диджитализация аудита в условиях COVID-19. Рассмотрены основные тенденциии диджитализации аудита в условиях трансформации экономики. Установлено, что аудит должен проводиться в полном соответствии с международными стандартами аудита, несмотря на проблемы, связанные с COVID-19. Обосновано, что технологическая интеграция аудита на базе современных информационных систем повышает эффективность аналитической работы аудитора.

Ключевые слова: эко-тревожность, коронавирус, COVID-19, диджитализация, аудит.

Background. The global pandemic 2019-2020 is changing not only the lives of citizens, but also approaches to business management. As of 16.05.2020, a total of 4648205 patients were registered in the world [1]. Due to the inability of citizens to buy goods and services, companies are revising their business plans and development strategies, some of them are losing profits due to restrictions on activities. The real challenge for entrepreneurs was the long-term introduction of quarantine. Businesses are forced to work remotely, via the Internet, reformatting their customers to buy online. According to the study by the international audit company Deloitte, the biggest impact of the COVID-19 pandemic on business may be a decrease in sales and cash flow (61\%), inability to serve consumers / customers $(52 \%)$ and inability to continue normal business management $(46 \%)[2]$.

The global pandemic and the activities of audit companies have not escaped. Audit is developing rapidly, has passed the stage of formation and continues to gain momentum. Intensive development of information and computer 
technologies and the world wide web is the reason for the emergence of new and modern approaches to building accounting and analytical support of business entities and its audit support, which increases the dynamism of business processes, which is extremely important in times of limited activities.

Analysis of recent researches and publications. Modern scientists pay much attention to problems solving of theoretical, organizational and methodological support of audit in terms of information technology, such as M. Benko [3] has studied information technology as a factor that, along with other factors, determines and promotes the integration of internal and external audit; M. Bilukha [4] analyzed the directions of development of accounting and control of electronic technology in the XXI century; G. Bowman [5] studied the impact of digitalization on a large number of European small and medium enterprises. N. Wengeruk [6] identified the problem of taking into account the risks of computer audit, studied the risks inherent in auditing computer data processing. S. Ivakhnenkov $[7 ; 8]$ developed audit software for data analysis. K. Nazarova [9] studied the synergy of external and internal audit. L. Larikova [10], considered procedures for creating a comprehensive audit automation system. R. Lisova [11] determined the effects of digital technologies on different types of business activity of companies and changes in their business models. T. Mats [12] studied the problems of auditing in the environment of management information systems. Ye. Mnykh analyzed the technological integration of analysis, accounting and their risks on the basis of modern information systems, I. Podik, M. Rahinger studied the impact of digitalization on the innovation of business models, L. Sokolenko devoted works of digitalization of accounting at enterprises, A. Shaforostov studied the documenttation of audit and accounting for ISA and IFRS and others [13-19]. However, the problematic and debatable issues that have been left out of these scholars need a solution to formulate a comprehensive approach to audit digitization in an economic transformation and the limited business practices caused by the global pandemic of 2019-2020.

The aim of the article is to determine the role of digitization in the financial spheres, in particular in the sphere of audit, to study the results of technology implementation in foreign countries and to identify promising areas of development for Ukraine in the conditions of COVID-19.

Materials and methods. The materials of the study were indicators of the spread of the COVID-19 pandemic in the world, publications of scientists, official reports of international organizations, regulations, etc. The theoretical and methodological basis consisted of general scientific and special methods of cognition, based on a dialectical approach to the consideration of economic processes is analyzed in the study. Different methods were used to solve the tasks such as methods of analysis and synthesis - to study the economic essence of the audit in terms of COVID-19; system approach to determine the methodological foundations of the enterprise management 
system; methods of general analysis, etc. General and specific methods of understanding the objective nature of economic phenomena and processes were used in the study to analyze the impact of the COVID-19 pandemic on business; methods of causation - to study the impact of digitalization on the audit process; methods of grouping and compilation, sample observation - for statistical data processing. Based on the methods of systems analysis and scientific abstraction, general conclusions are formulated. In addition, a set of complementary methods of scientific research of economic processes and phenomena using statistical and analytical materials, as well as the results of their own research have been inroduced.

Results. In March 2020, the Association of Chartered Certified Accountants (ACCA) decided to investigate the impact of COVID-19 on the work of companies [20]. It conducted a global survey and found that due to the crisis caused by the coronavirus pandemic, such a common action for accountants and auditors as attracting new clients has become a real problem (figure 1).

Despite the problems associated with COVID-19, audit should be conducted in full compliance with the standards, although in the circumstances, the completion of the audit may take longer. Therefore, the use of information technology simplifies the work of the auditor and involves conducting audits using computer technology.

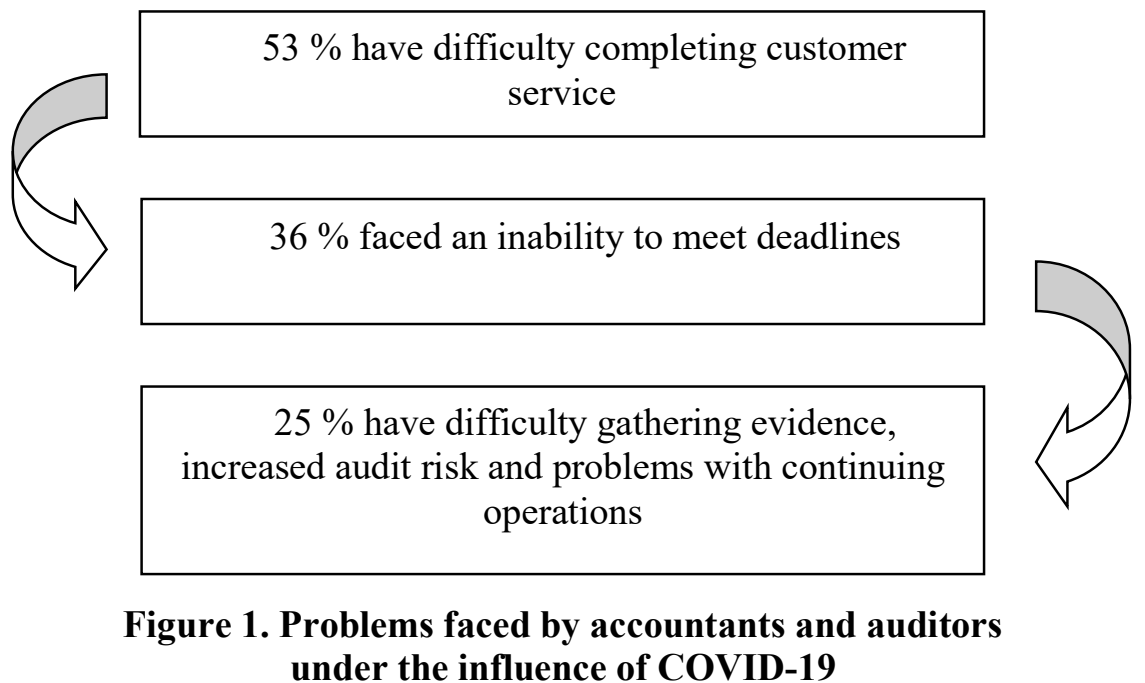

Source: developed by the authors on the basis of [21].

It simplifies the work of the IT auditor and provides audit for computer-assisted work. The use of computer technology can be applied at all stages of audit, namely during planning, implementation, documentation, reporting. The use of information technology does not alter the purpose of audit procedures, but it directly affects the order and methods of their conduct, audit planning process, the documentation process, the assessment of materiality and audit risk, as well as the determination of the content, scope, sequence and implementation of audit procedures and evaluation 
audit evidence. Due to the proliferation of the digitization process, there is a need to improve the methodology and tools for audit economic entities of different forms of ownership, in accordance with the challenges of today and to formulate a high-quality information base for managerial decisionmaking.

The transition of many companies to the mode of online and the processes of digital transformation are the driving force behind the change in the corporate world, the basis of which is the introduction of new technologies such as Big Data Analysis, Internet of Things, Cloud Technologies or 3D Printing. Analog information is being converted to digital data. The constant convergence of the physical and digital worlds encourages companies to integrate, for example, the Internet of Things and Services into production processes, to create value by analyzing and managing big data, which can be used as a competitive advantage. Most of the changes caused by digitization are destructive and fundamentally alter existing industries, companies holding dominant positions in the market face new competitors, existing business models have become obsolete and replaced by new ones [11].

According to the latest EY research [22], digitalization has great impact on business model components such as value proposition, internal infrastructure management and customer relationships. Predominantly changes in the form of new offerings (products, services, cloud packages, predictive services) are the driving factors behind the business model modification.

In recent years, the public has been increasingly paying attention to audit activities, as confidence in the information received is a necessary factor in the partners' trust. In this regard, the market for audit services in Ukraine is transformed by the directions and interests of clients who work in different business sectors and differ in ownership, management systems and financial condition. As more and more data is generated in connection with the digitization of companies, there is a need to develop auditor functions. For example, they include audit practice of forensics, tax audit, due diligence, management accounting, personnel audit and other related services. These audit and other services require an emphasis on understanding the specific risks of the business and developing an audit approach that is capable of responding effectively to those risks.

Computer technologies are also becoming more involved in the new role of auditor as they shift from testing tasks to more analytical approaches related to working with data. According to Hays' 2019 payroll and vacancy forecast, $40 \%$ of accounting and finance departments today are in demand for their operational and technical skills, compared to just $27 \%$ last year [23]. The growing amount of information needs to be used effectively for high quality audits and to enable auditors to focus more on risk identification and business understanding. The large volume and untapped potential of data generated by new technologies necessitates constant audit digitization. The functions of a professional auditor are changing in response to the digital transformation of companies. Using automation to increase data volumes 
can help to conduct high quality audits and allow auditors to focus more on risk identification and business understanding. This development of audit leads to greater interconnection and transparency and, as a consequence, greater stakeholder trust [24].

The issues of audit automation cover the whole complex of complex applied problems related to the use of information technologies in the control, audit and analysis of financial statements of enterprises, assessment of the efficiency and reliability of information technologies, as well as the organization of work of audit firms in modern conditions [8, p. 38].

Given the current high level of use of computer systems in business, the auditor should be competent, including in the field of typical computer information technology. Yes, it has the opportunity to use the services of a computer information technology specialist, but it should be noted that this increases the risk of non-detection and additional risk and increases the cost of audit [6, p. 35]. Lack of the necessary knowledge can lead to the doubt of the auditor's competence and conclusions. In addition, businesses are wishing not to publicize the data and may not like that a large number of individuals will have access to their information.

According to the International Audit and Assurance Standards Board (IAASB), the 2020-2023 strategy is designed to take into account the active development of technology, the new dynamic role of small and mediumsized enterprises and the changing needs of reporting information. The strategy also includes an action plan for 2020-2021. The main tasks for the outlined period are shown in figure 2 [25].

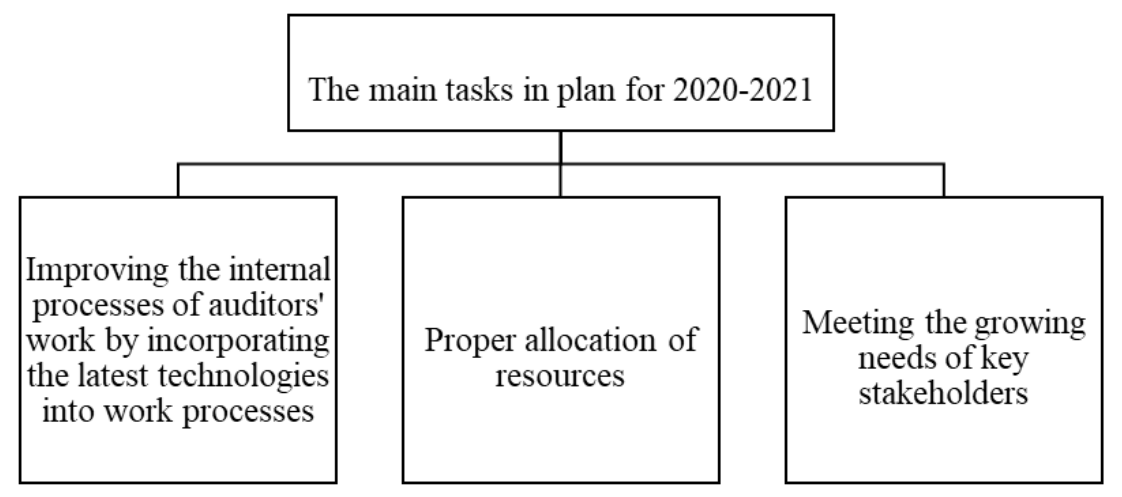

Figure 2. The main tasks in plan for 2020-2021

Source: developed by the authors on the basis of [25].

Given the progressive development of information technologies, there is an opportunity for their widespread use in the process of analytical processing of economic information, which helps to reduce the timing of audit, increase its responsiveness, more comprehensive coverage of factors that affect the results of financial and economic activity, obtaining the results of analysis, which are true [3]. With the introduction and application of computer information technology, the overall purpose and scope of audit will not change. 
The modern audit system is differentiated to meet the needs of different groups of consumers of information and integrated around a single database, which simultaneously collects all the primary information. Audit at the current stage of development should be designed based not only on the combination of different species, but also on the integration of many sciences [14].

Auditors can use and actively apply information technology both to improve audit methodology and to automate its organization. From an organizational point of view, audit should be considered as a computer, which involves the use of computers and modern information technology, which is directly organized by audit activity in the management information systems environment. This approach involves the use of information technology in the planning, control and documentation, in the course of audit and the preparation of audit report. The use of personal computers in audit allows to reduce the time spent on its conduct and as a result creates new opportunities in the organization and methodology of its conduct.

The auditor should have computer programs used to verify the contents of the enterprise files, as well as control data used for computer processing to verify the functioning of the enterprise computer programs.

It is in the interest of the auditor to automate his work, not in the interests of the enterprise. Therefore, it is necessary for audit programs to have the ability to process files in the formats common in Ukraine used in accounting software packages [12, p. 137].

Nowadays, there is a need and at the same time the possibility of new organizational and methodological approaches in solving accounting and audit problems. They are connected, on the one hand, with the transition to market relations and international standards, and on the other, with the widespread adoption of computer technologies [18, p. 253].

Information technologies used for accounting and reporting have a significant impact on the competitiveness of the decisions made, as they increase the speed of reporting and the reliability of management information by automating the procedures for its collection and processing.

As the composition of risks affecting the business of companies is constantly changing, and the organizational structure of companies is complicated in the development process, there is a periodic need to replace one information system with another. Company management often decides to update the information system only on the basis of experience of using different systems in other companies and comparing their organizational structure with the structure of their company. As a result, enterprises incur inefficient costs associated with the implementation of information systems, as this process is delayed, goes beyond the original budgets, testing programs and disclosing to staff their functionality is often carried out formally, as a result of which program functions are not fully used [20, p. 35].

Currently, auditors use to some extent general-purpose software, such as: spreadsheets; text editors; database management systems; programs of financial analysis of the activity of enterprises. These programs allow the 
auditors to organize the storage of data for their further processing and analysis of information on the objects of the conducted analysis, to perform some simple calculations, to prepare reports and conclusions [19, p. 42].

A market economy implies an increase in the requirements for baseline analytical information to support managerial decision-making. Methods of analysis on the basis of electronic computers can satisfy the requirements of complexity, systematicity, efficiency, accuracy of cognition, trends and patterns of its change and development. With the maximum formalization of analytical procedures with the help of electronic computers up to $80 \%$ of the technology of economic process is implemented.

The main information control systems presented in the Ukrainian market are aimed at audit automation. Strengthening audit position in Ukraine, bringing it closer to international audit standards and principles requires updating the ability and efficiency of using the latest audit organization technologies based on the use of the latest information technology.

The computer program should be able to correct the proposed method using the designer. It is also necessary that such a computer program be capable of importing information, for example, from Microsoft Excel, which is most actively used by both domestic and foreign auditors. The import of such data should adapt it to the computer program database, to the auditor's working papers, or, even on the basis of a specific algorithm, to form an audit report. With this conclusion, the auditor may or may not agree, because it is easier to analyze what is created than to formulate its own. In any case, this would significantly reduce the auditor's time spent directly on working documentation. However, this would provide an opportunity to focus on more important audit steps and procedures that the computer is not able to satisfy today, such as the professional judgment of an auditor based on his or her intuition.

Technological integration of audit on the basis of modern information systems improves the efficiency of analytical work by: expanding the capabilities of factor analysis; selection and solution of new multidimensional problems that are solved using economic-mathematical methods and models; increasing the efficiency and cost effectiveness of analytical procedures [13].

Assurance is given to the company by continuous audit. In recent years, it has been much easier to bring it to life with the rapid advancement of information technology, making it possible to report in real time and spend less resources, and thus be more practical and economical. But there must be more robust protection of corporate data.

The power of continuous audit is the intelligent and effective continuous testing and control of risks aimed at timely reporting of deficiencies to be immediately investigated and corrected. By changing the overall approach in this case, the auditors will develop a deeper understanding of the business environment and risks for the company and will stimulate business performance [7]. There are a large number of software products (figure 3). 


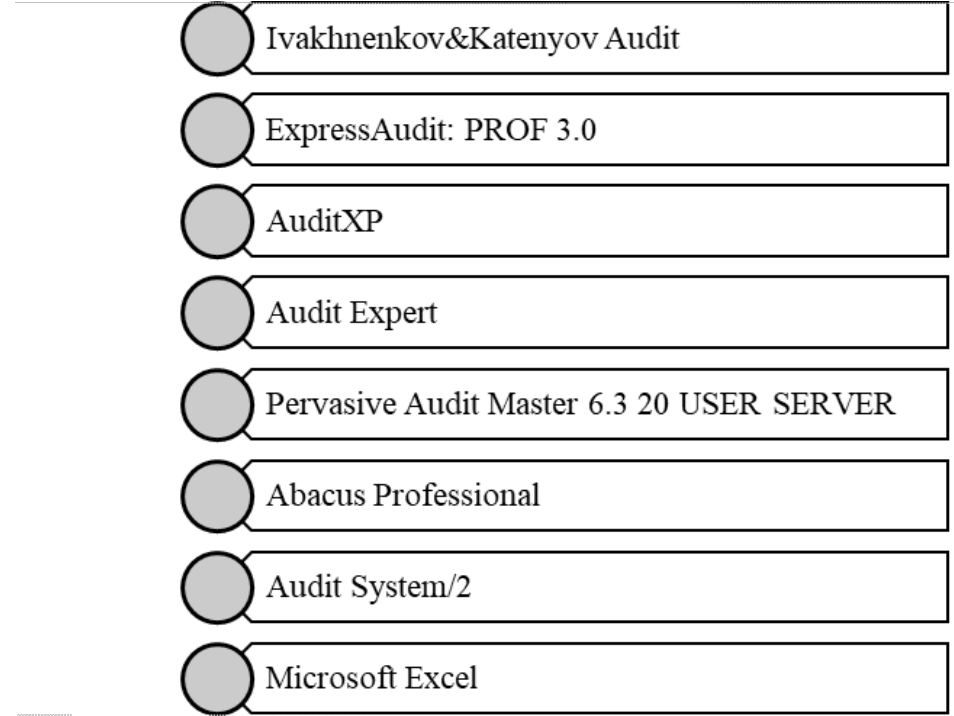

Figure 3. Software products of audit

Source: developed by the authors.

An alternative to the software product is the CaseWare software solution, which is used to automate the reporting process in accordance with International Financial Reporting Standards, strengthen internal control processes, and synchronize a large number of documents in different formats. CaseWare includes all stages of verification from customer acceptance and scheduling to reporting, importing and exporting information in Word, Excel, PDF and more; ability to download client data from 60 accounting packages, including $1 \mathrm{C}$, SAP. In addition, it provides an opportunity to obtain an overall consolidated balance according to the required format [22].

To date, audit firms have developed and utilized specialized information systems focused on the internal regulation of audit activities using internal corporate standards. Examples of such programs are systems of leading audit firms, such as KPMG, which uses the Vestor 6 program, Pricewaterhouse Coopers, which uses the My Client, and Deloitte\&Touche, which uses the Audit System/2. The main drawback of the organization of audit in Ukraine at the present stage is the low level of adaptability, which is manifested in the conduct of audits. Large and medium-sized Western audit firms use well-developed audit techniques that allow you to perform work quickly and efficiently. Therefore, increasing the adaptability of domestic audit firms is the only opportunity to compete with Western firms [10].

Microsoft Excel is used in audit both individually and in conjunction with Audit System/2, as the latter is also the product of Microsoft, which significantly speeds up the work of auditors. For this reason, Audit System/2 is actively used by audit market leaders. The direct use of Misosoft Excel in the audit is due to:

- the fact that official software products require considerable acquisition and installation costs; 
- most audit organizations consider software products to be ineffective and cost-effective, which again returns users to Microsoft Excel;

- the ability of computer audit programs to remove information about the activity of the enterprise from the relevant databases or to enter information about it and its accounting independently, if the accounting is conducted manually.

There are many inconsistencies in audit software products, although it cannot be denied that their quality has increased in recent years [13, p. 41-45]. Any business has questions about the use of software, as there are so many of them, they are all alike, but the enterprise chooses the best and the best for itself.

The current promising area of ICT is information systems that are cloud-based, which means infrastructure designed to provide ubiquitous access to storage devices, applications, and services over the Internet. Cloud technologies allow consumers to use applications without installing and accessing personal files from any computer that has Internet access [14].

Current trends look like the future of computer audit. Such activities will cover aspects that are closely related to the statutory audit of financial statements but at the same time cover a wide range of consulting services that auditors may provide:

- verification of algorithms of computer accounting systems of enterprises as audit clients and consulting on the issues of their proper construction;

- analysis of large arrays of financial and operational data in electronic form by special software to confirm and detect fraud;

- analysis of the activity of the enterprise and their forecasting with the help of a powerful mathematical apparatus of economic modeling and software;

- assistance to the company in matters of information security.

Lack of information is referred to as a major factor limiting the growth of audit automation, along with such a factor as the poor quality of the proposals available. However, for the most part, audit firms find it necessary to incorporate information technology into their operations, and expect that this will help improve their efficiency and quality.

Data protection in computer networks is becoming one of the most urgent problems in modern information and computer systems. The concept of data protection when using electronic computers includes both the development and implementation of appropriate security methods, and the constant use of them. Modern information technologies create conditions for the growth of unauthorized access to information and allow to perform complex procedures for its processing.

To ensure the protective functions of audit, data protection avoids the abuse of persons who have access to databases, which are especially common in doing business over the Internet. Practice shows that in the context of automated information processing systems, thefts of value are carried out with the participation of employees engaged in the processing of eco- 
nomic information. The main purpose of data protection of electronic computers is to prevent phenomena that adversely affect the performance [4]. Blockchain technologies provide the highest level of protection against external influences. The data contained in the system cannot be deleted or replaced. Such a database is characterized by anonymity, an agreed mechanism, it is not owned by a specific entity, is not controlled or regulated by third parties. All functions in a blockchain system are distributed among its members, who preapprove changes that may occur in the system. Thus, it is virtually impossible to make changes and edit after the transaction. Based on the above, blockchain technologies are ideal for accounting and audit because they keep track of all transactions and changes to the system, prevent manipulation and distortion.

Conclusion. Information technology enables the auditor to carry out audit quickly and efficiently, which will be based on accurate enterprise data. Both employees of the enterprise and the auditors must comply with the terms of confidentiality of the data. This enables the auditor to gain the trust and respect of his clients and competitors. Audit software must be safely secured, which is one of the conditions for guaranteeing work quality.

Thus, audit information technology is a set of methods and procedures that provides the functions of collecting, accumulating, storing, processing and transmitting data using technical means to achieve audit objective in the best possible conditions. The use of audit information technology does not replace audit process itself, but is merely a tool that minimizes time and resources. Based on a quality IT audit, the enterprise administration will be able to reasonably solve security and control problems; justify the purchase or upgrade of computer programs; plan to upgrade the skills of IT staff.

\section{REEERENCES}

1. COVID-19. Coronavirus pandemic. www.worldometers.info. Retrieved from https://www.worldometers.info/coronavirus [in English].

2. Businesses are preparing to reduce sales and cash flow due to the COVID-19 pandemic. Retrieved from https://www2.deloitte.com/ua/uk/pages/press-room/ press-release/2020/acc-and-deloitte-covid19-research.html [in English].

3. Benko, M., Sopko, V. (2015). Information technologies as a factor of internal and external audit integration. Economic Forum, 1, 254-262 [in English].

4. Bilukha, M. (2005). Main directions of development of accounting and control over electronic technology in the XXI century. Bulletin of KNUTE, 3, 13-17 [in English].

5. Bouwman, H., Nikou, S., Molina-Castillo F. (2018). The impact of digitalization on business models. Digital Policy. Regulation and Governance, 2, 105-124 [in English].

6. Venheruk, N. (2013). Audit risk in a computer environment. Scientific Bulletin of the National University of Life and Environmental Sciences of Ukraine. Avg. Economics, agrarian management, business, 181, 31-36 [in English]. 
7. Ivakhnenkov, S. (2009). Audit software for data analysis: the first Ukrainian experience. Accounting and Audit, 10, 38-45 [in English].

8. Ivakhnenkov, S. (2010). Control of financial information: modern technologies. Finance of Ukraine, 1, 87-97 [in English].

9. Nazarova, K. (2015). Audit: evolution, potential, efficiency. Retrieved from http://zt.knteu.kiev.ua [in English].

10. Larikova, L. (2009). Procedures for creating a comprehensive audit automation system. Auditor of Ukraine, 13-14, 54-59 [in English] [in English].

11. Lisova, R. (2019). The impact of digitization on business models: stages and tools of digital transformation. Scientific Bulletin of Uzhgorod National University, 24, 114-118 [in English].

12. Mats, T., Levchenko, Z. (2014). Organization of audit in the environment of management information systems. Bulletin of the Poltava State Agrarian Academy, 3, 135-138 [in English].

13. Mnykh, Ye., Barabash, N. (2010). Financial Analysis [in English].

14. Muravskyi, V. (2015). Risks of automation of accounting. Problems and prospects of economics and management, 1, 185-190 [in English].

15. Podik, I., Biletska, G., Kovtunovych, N. (2018). Normative and legal support of electronic audit in Ukraine: current status and prospects. Economy and State, 10, 37-41 [in English].

16. Rachinger, M., Rauter, R., Müller, C., Vorraber, W., Schirgi, E. (2018). Digitalization and its influence on business model innovation. Journal of Manufacturing Technology Management, 7, 95-124 [in English].

17. Sokolenko, L. (2019). Digitization of accounting at utilities. Black Sea. Economic Studies, 47, 158-161 [in English].

18. Stasyshen, M., Lysenko, A. (2014). Methodology and organization of accountting, analysis and audit of the use of production inventories. Collection of scientific works of the State Economic and Technological University of Transport. Ser.: Economics and Management, 28, 250-254 [in English].

19. Shaforostov, A. (2013). Welsome to AD. Audit documentation on ISA: what, when, why and how. Independent auditor, 1, 38-40 [in English].

20. Shuklov, L. (2013). Automation of accounting under IFRS: how to choose the information system and audit the effectiveness of its implementation. International accounting, 30, 35-43 [in English].

21. Covid-19 having significant impact on the world's auditors. www.accaglobal.com. Retrieved from https://www.accaglobal.com/gb/en/news/2020/april/ACCACovid-19-Research-Audit.html [in English].

22. CaseWare Ukraine. caseware.com.ua. Retrieved from http://caseware.com.ua [in English].

23. Audit of modern times - modern audit in Ukraine and in the world. www.auditoptim.com.ua. Retrieved from https://www.audit-optim.com.ua [in English].

24. Sidhu, H. (2019). EY. Auditization of the audit reflects the deeper transformations taking place in the business. Retrieved from https://www.ey.com/ en_US/digital-audit/audit-digitization-transformative-age.

25. Audit Trends - 2020: IAASB, Tax Reform, Digitization. Retrieved from http://www.visnuk.com.ua/.

The article submitted to editor's office on 20.05.2020. 
Нежива М., Міняйло В. Диджиталізація аудиту в умовах COVID-19.

Постановка проблеми. Світова пандемія 2019-2020 рр. змінює не тільки життя громадян, а й підходи до управління бізнесом. Не оминула світова пандемія $і$ діяльність аудиторських компаній.

Аналіз останніх досліджень і публікацій. Проблемні та дискусійні питання потребують вирішення, щзоб сформулювати комплексний підхід до диджиталізачіі аудиту в ході економічної трансформаиії та обмеженої ділової практики, спричиненої глобальною пандемією 2019-2020 рр.

Мета статті - визначення ролі диджиталізачї у фінансовій сфері, зокрема аудиту, вивчення результатів впровадження технологій у зарубіжних краӥнах та визначення перспективних напрямів розвитку для Украӥни в умовах COVID-19.

Матеріали та методи. Матеріалами дослідження слугували показники поширення пандемії COVID-19 в світі, публічні видання науковців, офіційні звіти міжнародних організацій, нормативно-правові акти тощчо.

Результати дослідження. У з6'язку з поширенням процесу диджиталізації виникає потреба у вдосконаленні методики та інструментарію здійснення аудиту. Перехід багатьох фірм на режим роботи онлайн та процеси циифрової трансформації стимулюють зміни в корпоративному світі. Для здійснення запобіжних функиій аудиту захист даних дає змогу уникнути зловживань особами, які мають доступ до баз даних, що є особливо характерними при веденні бізнесу через інтернет. Блокчейн-технології забезпечують найвищий рівень захищеності від зовнішнього впливу.

Висновки. Інформаційні технологї дають змогу швидко та якісно провести аудит, який буде спиратися на точні дані підприємства. Працівники підприємств і аудитори мають дотримуватися умов конфідениійності даних. Програмне забезпечення аудиту має бути надійно захищеним, що є однією з умов гарантування якісно проведеної роботи.

Ключові слова: екотривожність, коронавірус, COVID-19, диджиталізація, аудит. 